\title{
Impact of international labor migration on regional economic growth in Thailand
}

\author{
Katikar Tipayalai* (D)
}

*Correspondence:
katikar.tipayalai@c.mbox.
nagoya-u.ac.jp
Graduate School
of International
Development,
Nagoya University,
Furo-cho, Chikusa-ku,
Nagoya 464-8601, Japan

${ }^{*}$ Correspondence: katikar.tipayalai@c.mbox. nagoya-u.ac.jp of International Development Furo-cho, Chikusa-ku, Nagoya 464-8601, Japan

\begin{abstract}
The movement of labor in the Southeast Asia and particularly Thailand, which is home to more than half of all ASEAN migrant workers, is an issue of growing interest and increasing importance. As Thailand is now confronted with the new challenge of the so-called "middle-income trap", the Thai government has recently implemented the long-run economic development plan called "Thailand 4.0", focusing on high productivity and innovative creation from skilled foreign workers. To put Thailand 4.0 in action, the Eastern Economic Corridor (EEC), which is an example of region-based development, serves as a pilot project. However, while demand for high-skilled workers from developed countries increases, the majority of immigrants in Thailand is considered to comprise low-skilled workers from neighboring countries within ASEAN. This article, therefore, examines the impact of international labor migration on regional economic growth in Thailand from 2003 to 2015 through an econometric estimation of the production function by considering the economic consequences of immigration through production and productivity separately for skill-classified migrant workers. The findings empirically indicate that immigrants, and particularly high-skilled ones, have a statistically significant and positive impact on the growth of the regional economy as well as labor productivity in Thailand, thereby suggesting more attention should be paid to the role of regional area-based development policies as well as the ability of the host country to absorb high-skilled migrant workers.
\end{abstract}

Keywords: Immigration, Regional economic growth, Thailand 4.0, Production function

\section{Introduction}

In an era of global labor markets, the demand for foreign workers as an input of production in labor-importing countries is the major driver of international labor migration. It can be noticed that, in the tradition of the labor movement, the migration flow was overwhelmingly from less developed to more developed countries and has geographically occurred from the Global South to the Global North region. However, recent trends have shown a rapid increase in the flow of migrants from less-developed economies to newly emerging countries in the developing world, known as "South-South" migration (Ratha and Shaw 2007; Hujo and Piper 2010). The growing presence of migrant workers in the South has continuously sparked heated debate in migrant-receiving countries over both economic and social impacts of migrant intakes as well as the policy implications

(c) The Author(s) 2020. This article is licensed under a Creative Commons Attribution 4.0 International License, which permits use, sharing adaptation, distribution and reproduction in any medium or format, as long as you give appropriate credit to the original author(s) and the source, provide a link to the Creative Commons licence, and indicate if changes were made. The images or other third party material in this article are included in the article's Creative Commons licence, unless indicated otherwise in a credit line to the material. If material is not included in the article's Creative Commons licence and your intended use is not permitted by statutory regulation or exceeds the permitted use, you will need to obtain permission directly from the copyright holder. To view a copy of this licence, visit http://creativeco mmons.org/licenses/by/4.0/. 
for dealing with any difficulties regarding migrant workers (Paitoonpong 2011; Athukorala and Devadason 2012; Bryant and Rukumnuaykit 2013). Although there is a large body of literature related to the experiences of the traditional migrant-receiving countries in the North, ${ }^{1}$ it is perilous to generalize from these studies due to the different conditions of local labor markets, the economic developments and structures, and the distinctive consequences of the characteristics of migrant workers.

As far as I know, there are only few empirical studies on the economic impacts of immigrants on host countries in the South, and Thailand is no exception. In fact, Thailand has been one of the major migrant-destination countries in Southeast Asia for over a decade where concerns have arisen regarding the impact of immigration on economic growth. Further concerns have been fueled by the fact that Thailand, in more recent years, has been faced with the new challenge of the so-called "middle-income trap" (Jitsuchon 2012), an economic development situation in which the country is trapped between the competitive edge of low wages among developing countries and the high value-added market of more developed economies. This is mainly due to low private investment and productivity growth rates. Together with the declining trend in the fertility rate together with the aging population in Thailand, which may have the significant impacts on the availability of workforce in the labor market, these are identified in a considerable amount of economic empirical studies as potential pressures slowing down the Thai economy. In this respect, international labor migration is considered an important instrument to mitigate these effects of economic situation and population transition as well as to reverse the declining trend in fertility; it has now become a major factor of regional economic development strategy in several countries.

Nevertheless, the Thai government recently rolled out its long-run economic development plan called "Thailand 4.0": a 20-year national strategic plan (2017-2036) focusing on improvement of human resources, technologies, and investment in R\&D and infrastructure. The primary purpose of the Thailand 4.0 policy is to shift the country from intensive labor-driven growth or resource-based production that mostly relies on cheap, low-skilled labor and imported technologies to innovative-driven growth or a knowledge-based economy, which places more emphasis on high productivity and innovative creation from advanced skilled workers (Jones and Pimdee 2017). In principle, the Thailand 4.0 agenda is the continuous process of the development or evolution of the Thai economic structure based on innovation, $R \& D$, technology and high-quality services. Thailand 1.0 concentrated on farmer mechanization in an attempt to increase yields in the agricultural sector before Thailand 2.0 utilized cheap labor in light industry to turn raw materials into finished goods with a greater focus on household and domestic products such as garments and textiles. This was followed by concentrating on heavy industries in Thailand 3.0, which focused on more complex and assembly productions, such as electronic materials and automobiles, in order to make Thailand an industrial hub for exports and attract more foreign direct investments. Nevertheless, under Thailand 3.0, the country has been confronted with the significant challenges of growing income

${ }^{1}$ For the literature surveys, for example see Card (2001), Borjas (2003), and Ottaviano and Peri (2012) in the US; Akbari and DeVoretz (1992) in Canada; De New and Zimmermann (1994) in Germany; Ortega (2008) in Spain; Addison and Worswick (2002) in Australia. 
disparities, imbalanced economic development, and the middle-income trap; therefore, the value-based economy of the Thailand 4.0 policy aims to turn the Thai labor force into knowledge-based or skilled workers in order to reach high-income status.

To put Thailand 4.0 in practice, the Eastern Economic Corridor or EEC is offered as a pilot project. The recently launched EEC project concentrates on developing new infrastructure and enhancing long-term economic growth in the Eastern region of Thailand. ${ }^{2}$ Making the Eastern region of Thailand a destination of choice for high-skilled immigrants from high-income countries is one of the goals of this strategic plan. Therefore, by providing estimates for regional level, this study provides useful input to the EEC as well as other regional development projects in the future. To do so, this study estimates a production function using a panel data model for the period 2003-2015. The analysis is performed across different regions of Thailand. This regional breakdown further indicates the feasibility of examining the impacts of economic growth in regions which are often assumed to be the geographical units of immigration in a regional development study. To the best of my knowledge, no study has yet adopted this production function to study the economic growth impact of immigration at the regional level in Thailand, particularly with migrant workers distinguished into high-skilled and low-skilled immigrants. In this regard, the present study thus emphasizes the need to fill this knowledge gap, and focuses specifically on the Thai regions by exploring the issue of how economic growth is affected by foreign workers using a panel dataset in Thailand.

The structure of this article is structured as follows. Section 2 explains the recent trends and characteristics of foreign workers in Thailand and its regions. Section 3 reviews the theoretical underpinnings and the literature review regarding the impacts of foreign workers on economic growth and labor productivity. Section 4 illustrates the production function specification and the estimated model formulation, and then describes the employed data, variables construction, equations and methods used for the estimation. Results and further discussion are outlined in Sect. 5, while the last section (Sect. 6) presents conclusions with some policy implications.

\section{International labor migration in Thailand: some facts and figures about immigrants in Thailand and its regions}

According to the World Bank report (2017), the movement of population in Southeast Asia is an issue of increasing significance. Malaysia, Singapore, and Thailand combined are home to more than 6.5 million ASEAN migrant workers or approximately $96 \%$ of all migrant workers in Southeast Asia, and Thailand alone accounts for more than half of all ASEAN migrant workers. Thailand, while regarding itself as a developing country, has enjoyed a fast-growing economy since the mid-1980s due to the country's structural transformation from an agricultural to an industrial base, which came together with a rapid inflow of migrant workers, particularly from neighboring countries in the Southeast Asia-Cambodia, Myanmar, and Lao PDR (more than half of them from Myanmar). As a result, the majority of immigrant workers from these countries enter Thailand illegally, with around 2-3 million of the estimated overall number of irregular immigrants

\footnotetext{
${ }^{2}$ More details regarding the project can be found at: https://www.eeco.or.th/en/project/core-development-areas.
} 


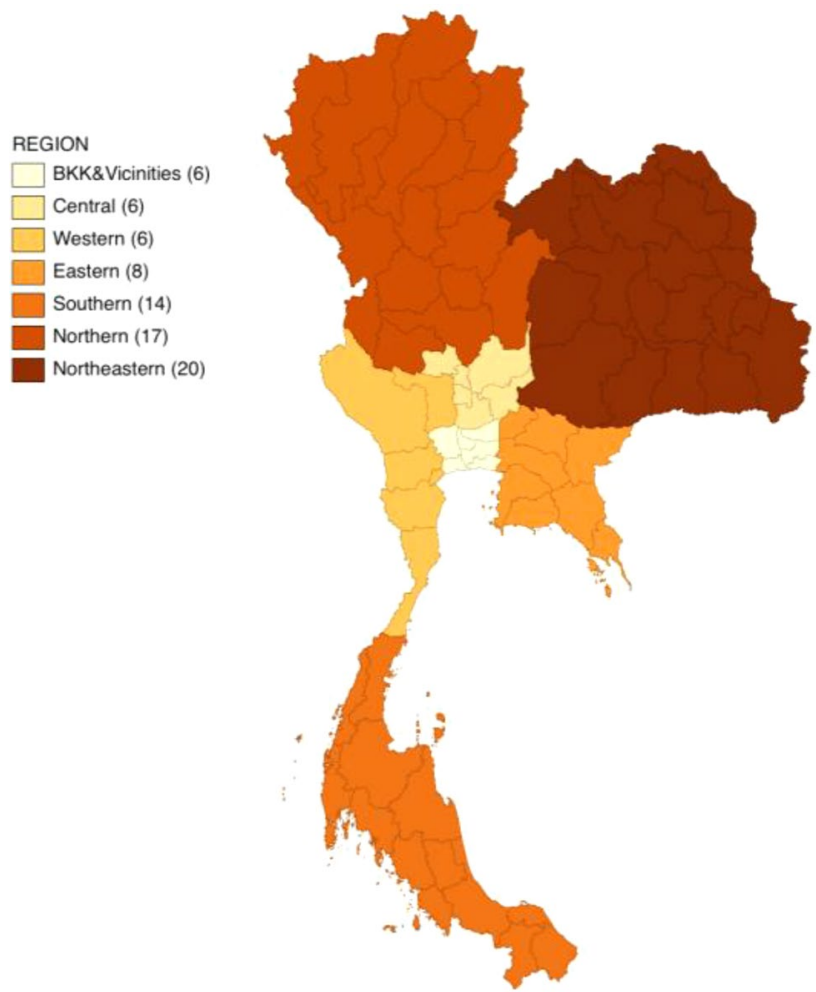

Fig. 1 Map of study regions in Thailand. Source: created by author using satellite data (2019)

in Thailand arriving in the late 1990s (Manning and Bhatnagar 2004; Chantavanich and Jayagupta 2009). This cross-border labor migration influx is primarily due to the increasing income disparities between Thailand and its neighbors, the relatively high wage, and the growing economy with greater labor demands from the expansion of industrial sector (Pholphirul 2013; Paitoonpong and Chalamwong 2012; Pholphirul and Kamlai 2014).

Regardless of the large-scale immigration, the increase in the foreign labor force in Thailand, most of them considered low-skilled workers, has led to a growing concern over its effects on productivity growth as well as on the native labor market. According to the Office of the National Economic and Social Development Board of Thailand (NESDB), Thailand has been divided into seven administrative sub-regions, which are the Bangkok and Vicinities, Central, Western, Eastern, Southern, Northern, and Northeastern regions (Fig. 1).

Though the Northeastern region is the largest region in terms of area and population, it is considered as the poorest region in Thailand, in which the GDP per capita is only one-third of the national average. This is mainly due to the geographical characteristics of this region, where there is less irrigated land, poor soil fertility, and water shortages during the dry season, which has thus resulted in low productivity in the agricultural sector. Therefore, there is no doubt that the number of immigrants residing in this region tends to be low.

In Thailand, more than $80 \%$ of foreign-born workers have tended to gravitate towards the Bangkok and Vicinities, Southern, and Eastern regions, and half of the 


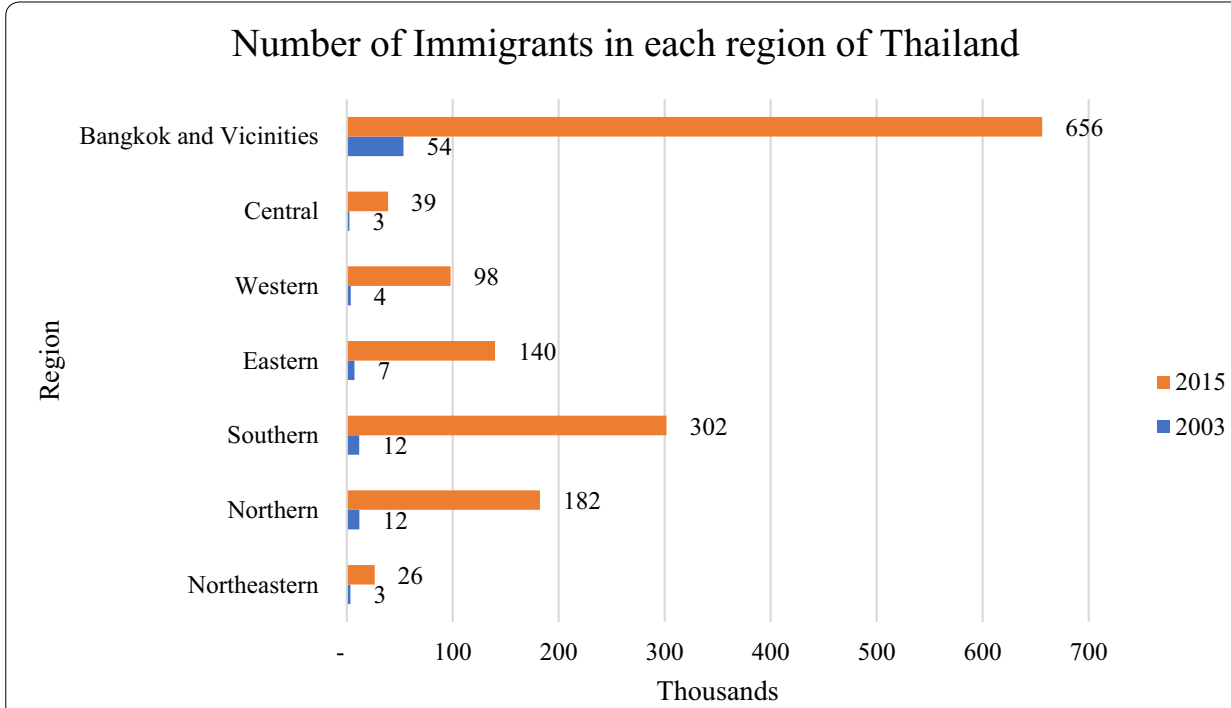

Fig. 2 Immigrant arrival rates, Thailand and Regions. Source: created by author using data from Office of Foreign Worker Administration in 2003 and 2015

immigrants have resided in Bangkok and Vicinities. These regions also account for about $90 \%$ share of high-skilled foreign workers and 75 percent of Thailand's GDP in 2015, where Bangkok and Vicinities region has the largest GDP in the country at $\$ 158.7$ billion, followed by the Eastern at $\$ 51.2$ billion, and Southern region at $\$ 25.9$ billion (NESDB 2019). As illustrated in Fig. 2, a significantly larger regional distribution of foreign workers in Thailand occurred between 2003 and 2015. However, the distribution of immigrant arrival rates in each region has not been changing over time. This is attributed to the development of the economic structure in the seven sub-regions of Thailand to attract and retain immigrants, particularly high-skilled immigrants from more developed countries. Most of the high-skilled immigrants are from Japan, followed by China, the Philippines, the UK, India, and the US. Immigrants from Japan and other developed countries are mostly expatriates who work as senior officials and managers in companies or industries, while migrant workers from India and the Philippines tend to work more in the educational sector as teachers, professors, or researchers. The primary goal of the project (i.e., EEC, SEC, and NEC) to attract and retain high-skilled immigrants in the different sub-regions of Thailand is to mitigate any adverse effects on the regional population of the economic situation and population transition due to the decline in fertility. Therefore, this study will provide some evidence of the economic growth effect of foreign workers at the regional level.

There are some reasons why the regional area is considered a suitable unit of analysis, rather than the province or country level. First, the foreign-born population and labor concentrate in clustered areas. To consider whether the distribution of immigrants is concentrated in clustered regions in the data, the geographical distributions of the percentage of foreign-born to native-born workers at the province level in both 2003 and 2015 are illustrated in Fig. 3, in which the provinces of Thailand are 
(a) Foreign-born to native-born workers (\%), 2003

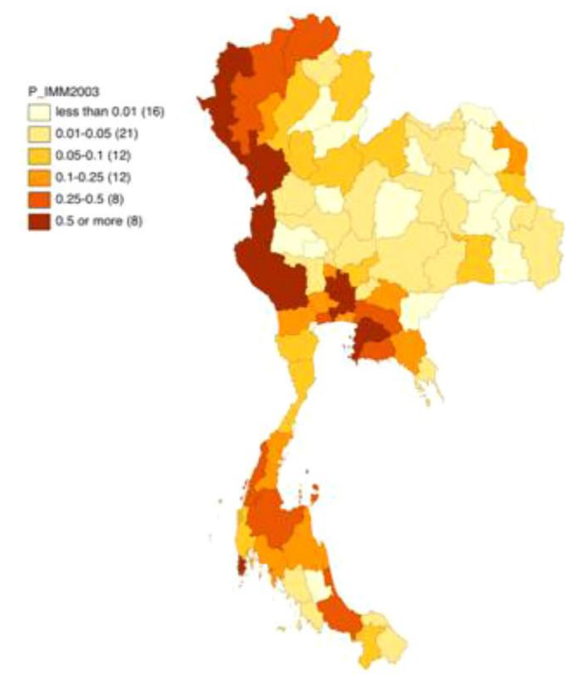

(b) Foreign-born to native-born workers (\%), 2015

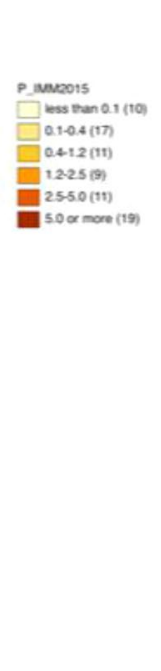

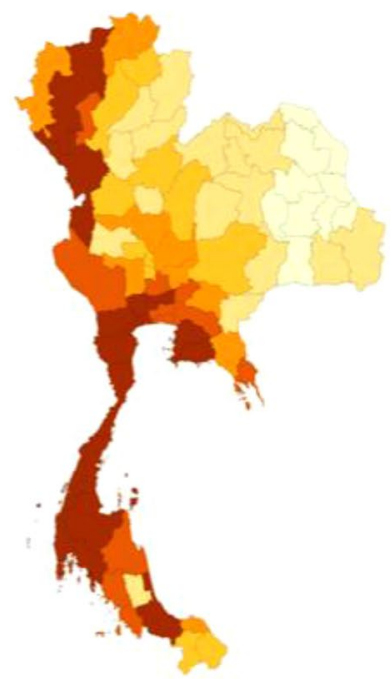

Fig. 3 Geographical distributions of foreign-born workers in Thailand. Source: created by author using data from Office of Foreign Worker Administration in 2003 and 2015

categorized into six levels. Figure 3 shows that the provinces with the highest proportion of foreign-born to native-born workers include an immigrant population of more than 0.5 and 5.0\%, compared with the lowest of less than 0.01 and 0.1 percent, in 2003 and 2015, respectively. Also, the higher percentage of immigrants to natives in 2015 are mostly clustered in the Northern, Western, Southern, Bangkok and Vicinities, and Eastern Regions, while they are less concentrated in the Northeastern and Central Regions. Therefore, immigration is mostly a result of chain migration and considering provinces alone is not sufficient. Furthermore, a regional area, by definition, is a more complete economic entity in terms of studying its economic growth and development, especially when the focus is on Thailand's regional area-based development under the Eastern Economic Corridor (EEC) project.

\section{Brief theoretical and literature review}

The objective of this section is to provide an overview of the main underlying theories and literature concerning the impacts of immigration on economic growth. The immigration phenomenon has both direct and indirect impacts on the migrant-receiving economy. While a direct effect of immigration comes from an increasing amount of labor supply, which helps to enhance economic output, an indirect impact comes from the possession of skills, knowledge, and abilities of migrant workers, which helps to supplement those of natives in the host country. In regards to this, there are two underlying theories which explain the relationship between immigration and its impacts on economic growth. A neoclassical view of the economic growth emphasizes that a country's population changes and technological progress are keys to its long-run economic growth, and ultimately to its convergence of growth (Solow 1956). That is, considering the economic growth exogenous, the growth rate of a region declines as the region becomes more and more developed. Hence, more developed regions and less developed 
regions will eventually have similar growth rates. However, some scholars have argued that there is a largely unexplained factor in the Solow growth theory, and they state that the skills, knowledge, and abilities of labors are the actual engines of economic growth (Lucas 1988; Dolado et al. 1994; Romer 1994; Hunt 2011; Peri 2012). An increase in the population not only increases the supply of labor and consumers, but also increases diversity of a population, which can result in increased innovation and technological advancement. According to Kremer (1993), a large population spurs innovation and technology by sharing knowledge and new ideas, and thus leads to economic growth. Unlike the exogenous growth or neoclassical theory, the endogenous growth model considers the concept of human capital as an endogenous growth factor that drives economic growth.

To cite some previous studies from the relevant literature, Ottaniano and Peri (2008) show that immigrants encourage firms to expand capacity and increase their investment, thereby resulting in increased productivity for both native and foreign workers. Using data from 22 countries, Boubtane et al. (2016) examine the contribution of migrant workers by skill levels. They find a sizeable positive impact of immigrants on labor productivity growth only in the countries where the ratio of high-skilled or highly educated migrant workers to native workers is relatively large. Furthermore, high-skilled immigration is often viewed as the determinant of growth and development. The influx of high-skilled immigrants can promote innovation and technological advancement by decreasing the costs of R\&D and also by increasing the number of patents (Bretschger 2001; Hunt 2011; Aydemir 2014).

Some relevant research examined the macroeconomic impact of migrant workers on receiving countries in Southeast Asia and found a positive association between immigration and GDP, although the impact is small (Martin 2007; Kanapathy 2011; Thangavelu 2012). Sussangkarn (1996), using a computable general equilibrium (CGE) model in Thailand, examined the impact of removing all migrant workers from the country and found that it leads to a decline in GDP per capita of $0.48 \%$. When the effect is disaggregated by economic sector, the decrease in per capita GDP becomes more acute in agricultural and low-skilled industrial sectors as they are where most migrant workers are located. Martin (2007) updated this research and showed that immigrants who are estimated to be around $5 \%$ of the total labor force in 2005 would enhance GDP by $1.25 \%$.

\section{Methods}

\subsection{Model and econometrics}

As discussed in the theoretical literature review, this study focuses on the empirical relationship of economic output with skill levels of migrant workers and the impact on regional economic growth by applying the standard production function. Economic output can be increased or decreased according to the quality of the production inputs, and particularly the quality of labor. In the present analytical framework, the differences between native and migrant workers as major production inputs are constructed in the model separately factoring in potential differences in productivity. Additionally, a distinction is made between the quality of the migrant workers in the analysis. $M_{H}$ and $M_{L}$ in this context thus capture migrant workers who are classified by the levels of skill. 
To obtain an econometric estimation of the impacts of the skill levels of migrant workers and native workers on regional economic growth in Thailand, the production function could be applied and written as follows:

$$
Y=f\left(K, N, M_{H}, M_{L}\right),
$$

where $Y$ denotes the net domestic product of a given regional economy (measured in Thai baht); $K$ refers to the physical capital (measured, again, in Thai baht); $N$ to native workers (measured in numbers); $M_{H}$ to high-skilled migrant workers (measured in numbers); and $M_{L}$ to low-skilled migrant workers (measured in numbers).

The production function specified by Eq. (1) is presumed to generate constant returns to scale (CRS). This indicates that the total income from output equals the total costs from inputs, or in other words, if input factors are increased by a factor $c$, the output factor will also increase in a proportion of $c$-fold.

The above function, which is estimated in its log-linear form, is expressed as:

$$
\ln Y=\beta_{0}+\beta_{1} \ln K+\beta_{2} \ln N+\beta_{3} \ln M_{H}+\beta_{4} \ln M_{L},
$$

where the coefficients $\beta_{1}, \beta_{2}, \beta_{3}$, and $\beta_{4}$ denote the rate of change in output due to physical capital, native workers, high-skilled, and low-skilled migrant workers, respectively.

Moreover, by dividing the overall standard production function in Eq. (2) with the total labor force $(L)$, the effects of the shares of high-skilled $\left(M_{H} / L\right)$ and low-skilled $\left(M_{L} / L\right)$ immigrants on labor productivity $(Y / L)$ can be estimated as:

$$
\ln (Y / L)=\beta_{0}+\beta_{1} \ln (K / L)+\beta_{2} \ln (N / L)+\beta_{3} \ln \left(M_{H} / L\right)+\beta_{4} \ln \left(M_{H} / L\right) .
$$

The estimation of Eqs. (2) and (3) was employed in panel regression analysis through three estimating models.

The first model is the pooled time-series cross-section estimation which combines all data from both cross-sectional effects of independent variables on total output and time-series effect within units. The model is performed under ordinary least squares (OLS) regression and therefore, applied to the present study the OLS regression model has the following shapes:

$$
\begin{aligned}
& \ln \left(Y_{\mathrm{it}}\right)=\beta_{0}+\beta_{1} \ln K_{\mathrm{it}}+\beta_{2} \ln N_{\mathrm{it}}+\beta_{3} \ln M_{\mathrm{Hit}}+\beta_{4} \ln M_{\mathrm{Lit}}+\varepsilon_{\mathrm{it}}, \\
& \ln (Y / L)_{i t}=\beta_{0}+\beta_{1} \ln (K / L)_{\mathrm{it}}+\beta_{2} \ln (N / L)_{\mathrm{it}}+\beta_{3} \ln \left(M_{H} / L\right)_{\mathrm{it}}+\beta_{4} \ln \left(M_{H} / L\right)_{\mathrm{it}}+\varepsilon_{\mathrm{it}},
\end{aligned}
$$

where $i=1,2, \ldots, \mathrm{n}$ refers to cross-section units (sub-regions in this case); $t=1,2, \ldots, \mathrm{n}$ is the number of the time-series index (year in this case); and $\beta$ are a vector of parameters, while $\varepsilon_{\mathrm{it}}$ is the error term with a mean value of zero.

However, the pooled time-series estimation using OLS regression may cause temporal autoregressive problems, multicollinearity and spatial heterogeneity to some extent. In order to deal with these possible errors, the second way of estimating production function gives rise to the panel data analysis through region-specific modeling using the random effects (RE) model. 
The following random effects (RE) models for estimating the regional economic and labor productivity impacts of immigration are given by:

$$
\begin{aligned}
& \ln \left(Y_{\mathrm{it}}\right)=\beta_{0}+\beta_{1} \ln K_{\mathrm{it}}+\beta_{2} \ln N_{\mathrm{it}}+\beta_{3} \ln M_{\mathrm{Hit}}+\beta_{4} \ln M_{\mathrm{Lit}}+u_{i}+\varepsilon_{\mathrm{it}}, \\
& \ln (Y / L)_{\mathrm{it}}=\beta_{0}+\beta_{1} \ln (K / L)_{\mathrm{it}}+\beta_{2} \ln (N / L)_{\mathrm{it}}+\beta_{3} \ln \left(M_{H} / L\right)_{\mathrm{it}}+\beta_{4} \ln \left(M_{H} / L\right)_{\mathrm{it}}+u_{i}+\varepsilon_{\mathrm{it}},
\end{aligned}
$$

where $u_{i}$ and $\varepsilon_{\text {it }}$ are assumed to be the two error term components of the random effects (RE) model: i.e., $u_{i}$ which is specific to the $i$ th cross-sectional error component and does not change over time; and $\varepsilon_{\mathrm{it}}$ which is the idiosyncratic error term.

The choice between the pooled time-series cross-section (pooled OLS) and the RE models was made through Breusch and Pagan (1980) Lagrange Multiplier (LM) test, which is designed to test for the RE model based on the OLS residual.

$$
\begin{aligned}
& H_{0}: \sigma_{u}^{2}=0 \\
& H_{1}: \sigma_{u}^{2} \neq 0
\end{aligned}
$$

Under the null hypothesis $\left(H_{0}\right)$, the BP-LM test statistic complies with the Chi-squared distribution with one degree of freedom or $\chi^{2}(1)$. A finding that the calculated LM-statistic is greater than the critical values of the conventional $5 \%$ levels of significance ${ }^{3}$ is taken as evidence that $\sigma_{u}^{2}$ is significantly different from zero, and hence the null hypothesis $\left(H_{0}\right)$ would be rejected in favor of the alternative hypothesis $\left(H_{1}\right)$. The rejection of the null hypothesis conceptually implies that the RE model is considered to be the appropriate model.

Nevertheless, the appropriate estimation method for the random effects (RE) models is based upon the properties of the two error term components. If the individual-specific component $\left(u_{i}\right)$ is uncorrelated or independent with the regressors, the OLS estimator for $\beta$ would be consistent and the overall error terms are known to be random and the application of random effects (RE) model would be appropriate. However, if the individual-specific component $\left(u_{i}\right)$ is correlated with the regressors, the OLS estimator would be inconsistent and the individual-specific component is the leftover variation in the dependent variable and must be treated as a further set of parameters to be estimated. Therefore, this gives rise to the third estimating models which is called a fixed effects (FE) model.

The fixed effects (FE) models for estimating the regional economic and labor productivity impacts of immigration are specified as:

$$
\begin{aligned}
& \ln \left(Y_{\mathrm{it}}\right)=\beta_{0}+\beta_{1} \ln K_{\mathrm{it}}+\beta_{2} \ln N_{\mathrm{it}}+\beta_{3} \ln M_{\mathrm{Hit}}+\beta_{4} \ln M_{\mathrm{Lit}}+\alpha_{i} d_{\mathrm{it}}+\varepsilon_{\mathrm{it}}, \\
& \ln (Y / L)_{\mathrm{it}}=\beta_{0}+\beta_{1} \ln (K / L)_{\mathrm{it}}+\beta_{2} \ln (N / L)_{\mathrm{it}}+\beta_{3} \ln \left(M_{H} / L\right)_{\mathrm{it}}+\beta_{4} \ln \left(M_{H} / L\right)_{\mathrm{it}}+\alpha_{i} d_{\mathrm{it}}+\varepsilon_{\mathrm{it}},
\end{aligned}
$$

\footnotetext{
${ }^{3}$ The critical values of $\chi^{2}(1,0.05)$ is 3.841
} 
where $d_{\mathrm{it}}$ is a dummy variable which has the value of one for region $i$ and zero otherwise; and $\alpha_{i}$ is the coefficient for the region $i$.

In the above equation, the subscript $i$ means that the intercepts are allowed to vary or differ across regions because all regions have their own characteristics. These characteristics are such as trade openness, industrial sectors, etc. Therefore, the fixed effects (FE) models allow each region to have its own intercept value that does not vary over the period of time. However, the FE model from estimating the transformed data using the OLS technique is applied to provide consistent estimators. In other words, the fixed (or within) effects model offers a reasonable approach to estimating when there is unobserved heterogeneity across units, and the individual-specific effects are correlated with the regressors. In other settings, the random effects model might be more appropriate if the individual-specific effects are distributed independently of the regressors (Greene 2003).

Hence, the choice between the RE and FE models was made through the Hausman test, which is designed to test whether the individual errors $\left(u_{i}\right)$ are correlated with regressors:

$$
H=\left(\hat{\beta}_{\mathrm{RE}}-\hat{\beta}_{\mathrm{FE}}\right)^{\prime}\left[\operatorname{Var}\left(\hat{\beta}_{\mathrm{RE}}\right)-\operatorname{Var}\left(\hat{\beta}_{\mathrm{FE}}\right)\right]\left(\hat{\beta}_{\mathrm{RE}}-\hat{\beta}_{\mathrm{FE}}\right),
$$

where $\hat{\beta}_{\mathrm{RE}}$ and $\hat{\beta}_{\mathrm{FE}}$ are the vectors of random and fixed effects models estimates.

Under the null hypothesis $\left(H_{0}\right)$, the Hausman test statistic complies with a Chi-squared distribution with the number of degrees of freedom equal to the number of regressors in the model. The calculated Hausman-statistic that is greater than the critical values of the conventional $5 \%$ levels of significance is taken as evidence that there is a significant difference between the RE and FE estimators, and hence the null hypothesis $\left(H_{0}\right)$ would be rejected in favor of the alternative hypothesis $\left(H_{1}\right)$. The rejection of the null hypothesis conceptually implies that the FE model is considered to be the appropriate model.

\subsection{Data and variable construction}

As mentioned before, this study uses the regional area as the geographical unit of analysis. The data used as a dependent variable or a measure for regional economic growth come from the Office of the National Economic and Social Development Board of Thailand (NESDB). The NESDB has divided Thailand into seven sub-regions, which are the Northeastern, Northern, Southern, Eastern, Western, Central, and Bangkok and Vicinities Regions, and provided real regional GDP or gross regional product (GRP) as the sub-region counterpart of the national GDP. Changes in real GRP that captures the changes of a regional area's aggregate economic activities and performance serves as a proxy for economic growth.

The key independent variables in this research are native-born employment and foreign-born employment, the latter divided again in terms of different skill levels. In the regression analysis, the logged number of different skill levels of foreign-born workers is used as the key explanatory variable. The native-born employment is defined as the number of Thai people between the ages of 15 and 60 who are working part- or fulltime or actively seeking employment. The data are obtained from the Thai Labor Force 
Survey (LFS) and population and housing censuses, which are available electronically on the website of the National Statistical Office of Thailand (NSO).

For this study, foreign-born employment data are classified into two major categories: high-skilled and low-skilled foreign workers. While low-skilled foreign workers are mainly from neighboring countries in Southeast Asia (i.e., Myanmar, Cambodia, and Lao PDR), most of the high-skilled foreign workers are from Japan, China, the Philippines, the UK, India, and the US. Also, it should be recognized that the typology of migration in the context of Thailand is somehow arbitrary and the distinction between high-skilled and low-skilled foreign workers could be more administrative than usual. Foreign skilled workers refer to workers who have been granted visas to engage in work under section 9 (General category) and section 12 (Investment promotion category) of the Working of Aliens Act, B.E. 2551. In general, they are professional and managerial workers, investors, high-skilled technicians, and experts. Low-skilled foreign workers are those who hold temporary work permits which need to be renewed annually and entry into the country apart from the above categories. The data on foreign-born employment are compiled from the electronic data files of the annual report conducted by the Foreign Workers Administration Office of the Ministry of Labor.

The most important control variable is the physical capital of the regional areas, as labor and physical capital are the two basic inputs in a production function. A fixed asset is the measure for capital stock. However, the NESDB provides fixed assets only at the national level. Therefore, capital stock series for the regional level were generated through the method developed by Garofalo and Yamarik (2002) using the national measure of fixed assets multiplied by the ratio of region-level personal income to the national personal income. The regional level capital is calculated separately for each industry and then totaled across all industries. This method is also used for an immigration study by Peri (2012) as capital control at the state level. Following this method, this research calculated the regional personal income over the national personal income (Eq. 10), then summarized it through all the industries (Eq. 11):

$$
\begin{aligned}
& K_{i j t}=\left[\frac{y_{i j t}}{Y_{j t}}\right] K_{j t}, \\
& K_{i t}=\sum_{j=1}^{n} K_{i j t},
\end{aligned}
$$

where $i$ denotes regional area; $j$ denotes industry; $y$ is the personal income in a regional area; $Y$ is the national personal income, and $K$ is the capital measured by fixed assets. $n$ denotes the total number of industries, and the NESDB's fixed asset report provides the national values of 14 aggregated industries. ${ }^{4}$

\footnotetext{
${ }^{4} 14$ aggregated industries in Thailand are: (i) agriculture, forestry and fishing; (ii) construction; (iii) mining and quarrying; (iv) electricity, gas and water supply; (v) manufacturing; (vi) wholesale and retail trade, repair of motor vehicles and motorcycles; (vii) hotels and restaurants; (viii) transport, storage and communications; (ix) education; (x) real estate, renting and business activities; (xi) financial intermediation; (xii) public administration and defense; (xiii) health and social work activities; and (xiv) other community, social and personal service activities.
} 
Panel data are then constructed as in Eqs. (2) and (3), covering the period 2003-2015 across the seven sub-regions of Thailand.

\section{Results and discussion}

In order to analyze the regional economic impacts of foreign workers in Thailand, the data used to estimate the standard production function are arranged in a balanced panel data form by pooling time-series annual data and all cross-sectional units across the seven regions for 13 years from 2003 to 2015. The descriptive statistics for all variables used in the estimation are first presented in Table 1.

The results in Table 1 show that there is a significant difference and variability in the observed variables which could be due to the large disparities in the characteristics of labor markets in each region and the differences in the size of regional economies. Also, the prevalence of economic cycles emerging over time that are attributed to several economic situations are generally perceived to be varied and different across regions. The standard production function in this study is therefore estimated using both random and fixed effects model. The random and fixed effects models correct for both temporal and spatial heterogeneity that may arise in using pooled-OLS procedures.

The estimated results of an aggregate production function regarding Eqs. (4), (6) and (8) are presented in Table 2 in order to estimate the impact of immigration on economic growth at the regional level in Thailand. Table 2 provides pooled-OLS, random effects, and fixed effects production functions, which are estimated by splitting the skill level attainment variable for migrant workers into high-skilled and low-skilled migrant workers. Pooled OLS estimation shows that native-born and high-skilled foreign-born workers have statistically significant positive effects on regional economic output. Also, the results suggest that although immigrant workers do have a positive impact on regional economic growth, compared to native workers, the magnitude is much smaller. This suggests that an overall increase in migrant workers is good, but not as much as an increase in natives. In the case of low-skilled migrant workers, the positive and statistically significant effects on regional economic output are also found. In this context, a 10\% increase in employment of high-skilled $\left(M_{H}\right)$ and low-skilled $\left(M_{L}\right)$ foreign workers increased overall economic growth by about $0.9 \%$ and $0.1 \%$, respectively.

The model is then estimated using RE and FE estimators and the estimated results are compared using the Hausman test. The Hausman test statistics are overwhelmingly significant at the $1 \%$ level. The test decisively rejects the null hypothesis while using the RE estimator that the individual-specific effects are not independently distributed

Table 1 Descriptive statistics

\begin{tabular}{llllll}
\hline Variables & Mean & Maximum & Minimum & Std.dev. & Observations \\
\hline GRP $^{\mathrm{a}}$ & $1,132,811$ & $4,809,895$ & $248,566.4$ & $1,189,019$ & 91 \\
Physical capital $^{\mathrm{b}}$ & $247,304.9$ & $1,031,862$ & $53,357.35$ & $274,807.4$ & 91 \\
Native-born workers & $5,351,389$ & $12,969,995$ & $1,569,365$ & $3,431,517$ & 91 \\
Foreign-born workers & $138,660.7$ & 884,829 & 2617 & 170,505 & 91 \\
Low-skilled immigrants & 123,324 & 820,423 & 383 & $154,371.3$ & 91 \\
High-skilled immigrants & $15,336.68$ & 99,051 & 623 & $23,777.93$ & 91 \\
\hline
\end{tabular}

a, $b$ Millions of baht unit 
Table 2 Immigration and regional economic growth in Thailand, 2003-2015

\begin{tabular}{|c|c|c|c|c|c|c|}
\hline \multicolumn{7}{|c|}{ Dependent variable: regional economic output } \\
\hline & \multicolumn{2}{|l|}{ Pooled OLS } & \multicolumn{2}{|l|}{ Random effects } & \multicolumn{2}{|l|}{ Fixed effects } \\
\hline & NCR & CR & NCR & CR & NCR & CR \\
\hline $\ln K$ & $\begin{array}{l}0.7610 \\
{[0.0094]^{* * *}}\end{array}$ & $\begin{array}{l}0.7506 \\
{[0.0090]^{* * *}}\end{array}$ & $\begin{array}{l}0.8158 \\
{[0.0203]^{* * *}}\end{array}$ & $\begin{array}{l}0.8196 \\
{[0.0200]^{* * *}}\end{array}$ & $\begin{array}{l}0.9988 \\
{[0.0758]^{* * *}}\end{array}$ & $\begin{array}{l}0.9054 \\
{[0.0541]^{* * *}}\end{array}$ \\
\hline $\ln N$ & $\begin{array}{l}0.1740 \\
{[0.0077]^{* * *}}\end{array}$ & $\begin{array}{l}0.1499 \\
{[0.0045]^{* * *}}\end{array}$ & $\begin{array}{l}0.1299 \\
{[0.0322]^{* * *}}\end{array}$ & $\begin{array}{l}0.1006 \\
{[0.0177]^{* * *}}\end{array}$ & $\begin{array}{l}0.0286 \\
{[0.0476]}\end{array}$ & $\begin{array}{l}0.0121 \\
{[0.0467]}\end{array}$ \\
\hline $\ln M_{H}$ & $\begin{array}{l}0.0854 \\
{[0.0075]^{* * *}}\end{array}$ & $\begin{array}{l}0.0902 \\
{[0.0074]^{* * *}}\end{array}$ & $\begin{array}{l}0.0793 \\
{[0.0135]^{* * *}}\end{array}$ & $\begin{array}{l}0.0722 \\
{[0.0024]^{* * *}}\end{array}$ & $\begin{array}{l}0.0793 \\
{[0.0135]^{* * *}}\end{array}$ & $\begin{array}{l}0.0850 \\
{[0.0114]^{* * *}}\end{array}$ \\
\hline $\ln M_{L}$ & $\begin{array}{l}0.0107 \\
{[0.0029]^{* * *}}\end{array}$ & $\begin{array}{l}0.0093 \\
{[0.0028]^{* * *}}\end{array}$ & $\begin{array}{l}0.0052 \\
{[0.0034]}\end{array}$ & $\begin{array}{l}0.0077 \\
{[0.0024]^{* * *}}\end{array}$ & $\begin{array}{l}-0.0016 \\
{[0.0028]}\end{array}$ & $\begin{array}{l}-0.0024 \\
{[0.0028]}\end{array}$ \\
\hline Constant & $\begin{array}{l}4.2258 \\
{[0.2075]^{* * *}}\end{array}$ & $\begin{array}{l}4.8384 \\
{[0.1329]^{* * *}}\end{array}$ & $\begin{array}{l}3.5959 \\
{[0.4315]^{* * *}}\end{array}$ & $\begin{array}{l}3.9919 \\
{[0.2318]^{* * *}}\end{array}$ & $\begin{array}{l}0.6047 \\
{[1.5558]}\end{array}$ & $\begin{array}{l}3.1170 \\
{[0.6223]^{* * *}}\end{array}$ \\
\hline R-squared & 0.9972 & 0.9972 & 0.9611 & 0.9611 & 0.9687 & 0.9687 \\
\hline Observations & 91 & 91 & 91 & 91 & 91 & 91 \\
\hline Regions & 7 & 7 & 7 & 7 & 7 & 7 \\
\hline $\begin{array}{l}\text { Breusch-Pagan } \\
\text { LM test }^{a}\end{array}$ & - & - & $x^{2}(1)=137.64^{* * *}$ & - & - & - \\
\hline Hausman test ${ }^{b}$ & - & - & - & - & $x^{2}(4)=32.24^{* * *}$ & - \\
\hline
\end{tabular}

NCR and CR indicate non-constraint and constraint regression model, respectively Robust standard errors are in parentheses

$*, * *,{ }^{* * *}$ indicate significant at $10 \%, 5 \%$, and $1 \%$ level of significance, respectively

a Random effects versus pooled-OLS estimations test

b Fixed versus random effects model test

of the regressors, and supports the specification of the fixed effects estimator. Therefore, in interpreting the econometric results the main focus is on the fixed effects model estimates, while the random effects model is also estimated in this study for reference purposes.

The fixed effects (FE) model in Table 2 shows that the high-skilled foreign-born workers variable $\left(M_{H}\right)$ is statistically highly significant, while other types of workers become statistically insignificant. Nonetheless, the estimated results are consistent with the hypothesis that the existence of high-skilled immigrants boosts regional economic growth, although on a small scale. In relation to the high-skilled foreign-born workers variable $\left(M_{H}\right)$, the estimated result suggests that only an increase of around $0.8-0.9 \%$ in output growth compared to a $10 \%$ increase in the degree of high-skilled foreign workers.

Furthermore, estimating the impacts of immigration on economic output for each region in Thailand shows a $10 \%$ increase in employment of high-skilled $\left(M_{H}\right)$ significantly increased economic output in Eastern, Western, and Central region by about $0.72 \%, 0.74 \%$ and $1.48 \%$, respectively (Table 3 ). The impacts of low-skilled immigrants on economic output were mostly found to be insignificant, except for the Northeastern region. The results of immigration's impacts on output growth suggest the characteristic differences among sub-regions of Thailand, where the share of immigrants who are relatively high-skilled and mostly employed in manufacturing and services sectors as senior managers and professionals as a mean of foreign investment are more concentrated in the Eastern, Western, and Central regions of Thailand. Low-skilled immigrants from 
Table 3 Immigration and economic growth in Thailand by region, 2003-2015

\begin{tabular}{llllllll}
\hline \multicolumn{1}{l}{ Dependent variable: economic output } \\
\hline & North Eastern & Northern & Southern & Eastern & Western & Central & BKK and Vicinities \\
\hline $\ln K$ & 1.194 & 1.037 & 1.108 & 0.936 & 1.333 & 0.751 & 1.362 \\
& {$[0.144]^{* * *}$} & {$[0.186]^{* * *}$} & {$[0.113]^{* * *}$} & {$[0.072]^{* * *}$} & {$[0.311]^{* * *}$} & {$[0.035]^{* * *}$} & {$[0.059]^{* * *}$} \\
$\ln N$ & -0.041 & 0.081 & 0.267 & 0.003 & 0.046 & 0.486 & -0.016 \\
& {$[0.079]$} & {$[0.171]$} & {$[0.183]$} & {$[0.062]$} & {$[0.255]$} & {$[0.112]^{* * *}$} & {$[0.020]$} \\
$\ln M_{H}$ & 0.063 & 0.091 & 0.032 & 0.072 & 0.074 & 0.148 & 0.015 \\
& {$[0.045]$} & {$[0.050]$} & {$[0.028]$} & {$[0.026]^{* *}$} & {$[0.037]^{*}$} & {$[0.027]^{* * *}$} & {$[0.019]$} \\
$\ln M_{L}$ & -0.029 & -0.019 & -0.007 & -0.002 & -0.010 & -0.004 & 0.0003 \\
& {$[0.014]^{*}$} & {$[0.012]$} & {$[0.007]$} & {$[0.004]$} & {$[0.019]$} & {$[0.003]$} & {$[0.002]$} \\
Constant & -2.785 & -1.023 & -5.338 & 2.428 & -7.751 & -0.414 & -8.412 \\
& {$[3.752]$} & {$[4.008]$} & {$[3.105]$} & {$[1.727]$} & {$[8.306]$} & {$[1.729]$} & {$[1.314]^{* * *}$} \\
\multirow{2}{*}{ R-squared } & 0.986 & 0.959 & 0.983 & 0.997 & 0.920 & 0.998 & 0.998 \\
Observations & 13 & 13 & 13 & 13 & 13 & 13 & 13 \\
\hline
\end{tabular}

Standard errors are in parentheses

$*^{* * *},{ }^{* * *}$ indicate significant at $10 \%, 5 \%$, and $1 \%$ level of significance, respectively

neighboring countries are mostly absorbed in economic sectors which tend to be labor intensive but low productivity in other regions of Thailand such as agriculture, fishery, construction, and domestic work sectors.

By dividing the overall standard production function in Eq. (2) with the total labor force $(L)$, the effects of high-skilled $\left(M_{H} / L\right)$ and low-skilled $\left(M_{L} / L\right)$ immigrant shares on labor productivity $(Y / L)$ can be estimated. Table 4 provides the results of the pooled OLS, and random effects, and fixed effects estimations. The results from RE and FE

Table 4 Immigration and labor productivity in Thailand, 2003-2015

\begin{tabular}{|c|c|c|c|c|c|c|}
\hline \multicolumn{7}{|c|}{ Dependent variable: labor productivity } \\
\hline & \multicolumn{2}{|l|}{ Pooled OLS } & \multicolumn{2}{|l|}{ Random effects } & \multicolumn{2}{|l|}{ Fixed effects } \\
\hline & NCR & CR & NCR & CR & NCR & CR \\
\hline $\ln (K / L)$ & $\begin{array}{l}0.7345 \\
{[0.0090]^{* * *}}\end{array}$ & $\begin{array}{l}0.7458 \\
{[0.0086]^{* * *}}\end{array}$ & $\begin{array}{l}0.7641 \\
{[0.0246]^{* * *}}\end{array}$ & $\begin{array}{l}0.8054 \\
{[0.0227]^{* * *}}\end{array}$ & $\begin{array}{l}0.9301 \\
{[0.0516]^{* * *}}\end{array}$ & $\begin{array}{l}0.8596 \\
{[0.0482]^{* * *}}\end{array}$ \\
\hline $\ln (N / L)$ & $\begin{array}{l}-1.1097 \\
{[0.2711]^{* * *}}\end{array}$ & $\begin{array}{l}0.1520 \\
{[0.0046]^{* * *}}\end{array}$ & $\begin{array}{l}-0.4058 \\
{[0.1184]^{* * *}}\end{array}$ & $\begin{array}{l}0.1065 \\
{[0.0105]^{* * *}}\end{array}$ & $\begin{array}{l}-0.5405 \\
{[0.1621]^{* *}}\end{array}$ & $\begin{array}{l}0.0521 \\
{[0.0422]}\end{array}$ \\
\hline $\ln \left(M_{H} / L\right)$ & $\begin{array}{l}0.0928 \\
{[0.0065]^{* * *}}\end{array}$ & $\begin{array}{l}0.0901 \\
{[0.0064]^{* * *}}\end{array}$ & $\begin{array}{l}0.0923 \\
{[0.0155]^{* * *}}\end{array}$ & $\begin{array}{l}0.0854 \\
{[0.0154]^{* * *}}\end{array}$ & $\begin{array}{l}0.0808 \\
{[0.0127]^{* * *}}\end{array}$ & $\begin{array}{l}0.0873 \\
{[0.0126]^{* * *}}\end{array}$ \\
\hline $\ln \left(M_{L} / L\right)$ & $\begin{array}{l}-0.0045 \\
{[0.0047]}\end{array}$ & $\begin{array}{l}0.0122 \\
{[0.0028]^{* * * *}}\end{array}$ & $\begin{array}{l}0.0004 \\
{[0.0016]^{* * *}}\end{array}$ & $\begin{array}{l}0.0027 \\
{[0.0015]^{*}}\end{array}$ & $\begin{array}{l}-0.0041 \\
{[0.0033]}\end{array}$ & $\begin{array}{l}0.0011 \\
{[0.0030]}\end{array}$ \\
\hline Constant & $\begin{array}{l}4.9198 \\
{[0.1261]^{* * *}}\end{array}$ & $\begin{array}{l}4.9036 \\
{[0.1261]^{* * *}}\end{array}$ & $\begin{array}{l}4.6501 \\
{[0.3349]^{* * *}}\end{array}$ & $\begin{array}{l}4.2304 \\
{[0.3207]^{* * *}}\end{array}$ & $\begin{array}{l}2.8063 \\
{[0.5959]^{* * *}}\end{array}$ & $\begin{array}{l}3.6302 \\
{[0.5548]^{* * *}}\end{array}$ \\
\hline R-squared & 0.9973 & 0.9973 & 0.9485 & 0.9485 & 0.9542 & 0.9542 \\
\hline Observations & 91 & 91 & 91 & 91 & 91 & 91 \\
\hline Regions & 7 & 7 & 7 & 7 & 7 & 7 \\
\hline Breusch-Pagan LM test ${ }^{a}$ & - & - & $x^{2}(1)=117.4^{* * *}$ & - & - & - \\
\hline Hausman test ${ }^{b}$ & - & - & - & - & $x^{2}(4)=34.57^{* * *}$ & - \\
\hline
\end{tabular}

NCR and CR indicate non-constraint and constraint regression model, respectively Robust standard errors are in parentheses

$*^{* *},{ }^{* * *}$ indicate significant at $10 \%, 5 \%$, and $1 \%$ level of significance, respectively

a Random effects versus pooled-OLS estimations test

b Fixed versus random effects model test 
Table 5 Immigration and labor productivity in Thailand by region, 2003-2015

\begin{tabular}{llllllll}
\hline \multicolumn{7}{c}{ Dependent variable: labor productivity } & \multicolumn{1}{c}{} \\
\hline & North Eastern & Northern & Southern & Eastern & Western & Central & BKK and Vicinities \\
\hline $\ln (K / L)$ & 0.993 & 1.317 & 0.991 & 0.922 & 1.080 & 0.717 & 0.811 \\
& {$[0.115]^{* * *}$} & {$[0.234]^{* * *}$} & {$[0.174]^{* * *}$} & {$[0.052]^{* * *}$} & {$[0.307]^{* * *}$} & {$[0.056]^{* * *}$} & {$[0.114]^{* * *}$} \\
$\ln (N / L)$ & -24.846 & 7.958 & -0.594 & -0.140 & 0.069 & 0.624 & -0.164 \\
& {$[30.027]$} & {$[3.924]^{*}$} & {$[0.731]$} & {$[0.225]$} & {$[2.661]$} & {$[0.976]$} & {$[0.617]$} \\
$\ln \left(M_{H} / L\right)$ & 0.102 & 0.001 & 0.031 & 0.077 & 0.052 & 0.196 & 0.148 \\
& {$[0.053]^{*}$} & {$[0.066]$} & {$[0.043]$} & {$[0.020]^{* * *}$} & {$[0.047]$} & {$[0.044]^{* * *}$} & {$[0.077]^{*}$} \\
$\ln \left(M_{L} / L\right)$ & -0.043 & 0.069 & -0.0003 & -0.003 & 0.011 & 0.005 & 0.009 \\
& {$[0.032]$} & {$[0.042]$} & {$[0.011]$} & {$[0.004]$} & {$[0.041]$} & {$[0.005]$} & {$[0.015]$} \\
Constant & 2.321 & -0.825 & 1.995 & 2.728 & 1.228 & 5.799 & 4.404 \\
& {$[1.314]$} & {$[2.458]$} & {$[1.892]$} & {$[0.629]^{* * *}$} & {$[3.128]$} & {$[0.830]^{* * *}$} & {$[1.575]^{* *}$} \\
R-squared & 0.990 & 0.954 & 0.905 & 0.990 & 0.764 & 0.990 & 0.966 \\
Observations & 13 & 13 & 13 & 13 & 13 & 13 & 13 \\
\hline
\end{tabular}

Standard errors are in parentheses

$*^{* * *},{ }^{* *}$ indicate significant at $10 \%, 5 \%$, and $1 \%$ level of significance, respectively

estimators are then compared using the Hausman test. The Hausman test statistics are again significant at the $1 \%$ level, which means the FE model is appropriate.

The results of all explanatory variables except the share of capital per labor and highskilled immigrants seemingly tend to vary on each estimation model, which may possibly be due to upward bias from not controlling or including several other determinants of labor productivity in the model such as innovation, technological investment, and physical infrastructure, as well as other political and social issues. Nonetheless, a $10 \%$ increase in the share of capital per labor $(K / L)$ would contribute to an increase in labor productivity $(Y / L)$ by about $7.3-9.3 \%$ (Table 4 ). This suggests that greater use of machinery and tools by regions increases capital intensity, making labor more efficient, and would enhance regional labor productivity. Therefore, regions with higher intensity of physical capital tend to show more productivity in the long term rather than those that have low physical capital intensity.

Even though the econometric estimations concerning the share of low-skilled immigrants $\left(M_{L} / L\right)$ and labor productivity $(Y / L)$ were mostly found to be negative and insignificant, the relationship between the high-skilled immigrant share $\left(M_{H} / L\right)$ and labor productivity $(Y / L)$ was found to be positive and significant. A $10 \%$ increase of highskilled foreign worker share would increase labor productivity by about $0.8-0.9 \%$. The breakdowns of such estimations by regional level as shown in Table 5 further suggested a positive and significant relationship between the high-skilled immigrant share and labor productivity in some particular regions of Thailand. A $10 \%$ increase of high-skilled foreign worker share increased labor productivity by about $1.02 \%$ in Northeastern, $0.77 \%$ in Eastern, 1.96\% in Central region and 1.48\% in Bangkok and Vicinities (Table 5). These results suggest that high-skilled migrant workers in Thailand who brought in the new ideas, inventions, and technological innovation have an enhancing effect on the efficiency of task specialization through the adoption of labor-saving or knowledge-based technology, and thus they help to increase labor productivity.

Overall, the result of this study shows that immigration, of high-skilled immigrants in particular, has a statistically positive and significant impact on regional economic 
growth in Thailand; however, the magnitude of the impact is rather small. Real regional economic output seems basically embedded in the market structure of regional areas through physical capital and performance of native-born workers, with the influx of immigrants, especially low-skilled immigrants, affecting only the margins. The study also shows that the low-skilled immigrants which are considered to be the majority of immigrants in Thailand and usually viewed the most adversely in terms of Thai regional economic development have an insignificant impact on economic growth, but the highskilled immigrants which the present study has confirmed. The Eastern, Western, and Central regions of Thailand were found to benefit most from the inflow of high-skilled immigrants. Moreover, the econometric estimations show that a rise in the share of high-skilled migrant workers also causes an increase of overall labor productivity. This results from the increased diversity of the labor force that bring in new ideas, inventions, investment, and technological innovation to produce a wider variety of goods and services, thus indicating greater social returns to higher skill effects. Many regions of Thailand such as the Northeastern, Eastern, Central, and Bangkok and Vicinities region substantially benefit from employing high-skilled migrants. Even though many immigrants are employed in the Northern and Southern region, their contributions in these regions are not yet clear. This may be due to the fact that most of them are considered to be low-skilled, employed in low productivity sectors.

The mostly insignificant impact of both native and low-skilled migrant workers on regional economic growth and productivity could possibly be related to the fact that the characteristics of these types of workers in each region of Thailand do not differ much from another as well as a more general issue of large numbers of undocumented and irregular low-skilled immigrants in the Thai labor market which should be addressed by the proper enforcement of migration policy. Evidently, immigration of low-skilled foreign workers, particularly irregular ones, causes a slight decrease in the low-skilled native wages as well as a decrease in technology investment by domestic firms, resulting in the reduction of overall labor productivity. This could imperil economic development in the long run. However, the low-skilled immigrants are considerable sources of labor supply, which helps to maintain the country's economic competitiveness. Therefore, it is necessary to appropriately manage and balance both economic costs and benefits of low-skilled migrant workers. Until now, it can be seen that the immigration management system in Thailand still lacks this stability due to weak and inconsistent implementation of migration policy.

\section{Conclusions}

During the past decade, Thailand has become a major migrant-receiving country in Southeast Asia whose population of high-skilled immigrants has gradually increased over the years. However, most existing studies have extensively focused more on lowskilled workers from other ASEAN countries, showing a lack of recognition of skilled immigrants in Thai labor markets (Martin 2007; Lathapipat 2010; Pholphirul and Rukumnuaykit 2010; Pholphirul and Kamlai 2014). The present study, therefore, aims to investigate the economic impact of both low-skilled and high-skilled foreign workers immigrating into Thailand's regional labor market. In this study, the regional economy has been used to estimate the economic growth impact of immigrants using the 
standard production function. Even though the empirical analysis conducted in this article may be simple, it somehow sheds a new light for future research in this understudied area in Thailand.

An important limitation of this study as previously mentioned in the paper is the extensive, but barely understood, underreporting number of undocumented and irregular low-skilled immigrants. Hence, it would be imprudent to put too much emphasis on the precise figures of immigration effects. Given that this article is a first attempt at this topic in Thailand, the sensitivity analysis of these findings with the estimation of irregular immigrants needs to be further examined. Certainly, more confirmation of the results could be obtained if one could study the regional economic growth impacts of those irregular migrant workers in Thailand. Also, it should be noted that although the econometric estimations are grounded on a conventional framework of economic analysis, some of the results illustrate insignificant effects of low-skilled immigrants on regional economic output which could be due to the reverse causality problem whereby low-skilled immigrants might not boost the regional economic growth, but instead the economic growth in the host country pulls in the low-skilled immigrants, and the endogeneity problem resulting from not controlling several other determinants of regional economic growth and labor productivity, given the lack of data. When more data are available, these results can be further examined and revised.

Nevertheless, this study reveals that Thailand has long been enjoying price competitiveness by greatly relying on cheap labor from the neighboring countries, which causes the country to become stuck in the middle-income trap. While it is evident that employing low-skilled immigrants can have short-term advantages in terms of economic output expansion and reductions in labor shortages, its contribution to regional economic development in the host country in the long run remains unclear. Since the inflow of high-skilled immigrants has a positive impact on regional economic growth, Thailand therefore should focus more on bringing in high-skilled foreign workers as they are likely to promote new innovation and technology, attract more foreign investment, increase knowledge transfer, and improve overall labor productivity. By offering more flexible entry regulations as well as tax and non-tax incentives and other business opportunities can attract high-skilled immigrant workers. In addition, the government itself should effectively invest in infrastructure and facilitation including research support and research institutes to engage in $R \& D$ activities focusing on regional area-based development such as the EEC development project, which can help to attract both foreign and domestic investment as well as high-skilled immigrants into the country.

Acknowledgements

The author would like to thank Professor Fujikawa Kiyoshi, two anonymous referees, and participants at the 3rd International Conference on Economic Structures at Ritsumeikan University, Japan, 18-19 March, 2019 for their valuable comments and suggestions on an earlier version of this article.

Authors' contributions

The author read and approved the final manuscript.

Funding

The author has received no funding.

Availability of data and materials

The datasets for the present study are available electronically and publically. Data on Gross Regional Product (GRP), as well as capital stock, are available from the website of the Office of the National Economic and Social Development Board of Thailand (NESDB). Data related to foreign-born employment are compiled from the electronic data files of the annual report conducted by the Foreign Workers Administration Office. Data for native-born employment are obtained 
from the Thai Labor Force Survey (LFS) and population and housing censuses, which are available on the National Statistical Office of Thailand (NSO) website.

\section{Competing interests}

The author declares no competing interests.

Received: 14 November 2019 Revised: 15 January 2020 Accepted: 5 February 2020

Published online: 13 February 2020

\section{References}

Addison T, Worswick C (2002) The impact of immigration on the earnings of natives: evidence from Australia micro data. Econ Rec 78(240):68-78

Akbari AH, Devoretz DJ (1992) The substitutability of foreign-born labour in Canadian-production: circa 1980. Can J Econ 25:604-614

Athukorala PC, Devadason ES (2012) The impact of foreign labor on host country wages: the experience of a southern host, Malaysia. World Dev 40(8):1497-1510

Aydemir AB (2014) Skill-based immigration, economic integration, and economic performance. IZA World Labor. https:// doi.org/10.15185/izawol.41

Borjas $G$ (2003) The labor demand curve is downward sloping: reexamining the impact of immigration on the labor market. Q J Econ 118:1335-1374

Boubtane E, Dumont JC, Rault C (2016) Immigration and economic growth in the OECD countries 1986-2006. Oxf Econ Pap 68(2):340-360

Bretschger L (2001) Labor supply, migration, and long-term development. Open Econ Rev 12(1):5-27

Breusch TS, Pagan AR (1980) The Lagrange multiplier test and its applications to model specification in econometrics. Rev Econ Stud 47(1):239-253

Bryant J, Rukumnuaykit P (2013) The labour market impacts of immigration to developing countries: evidence from a registration campaign in Thailand. J Dev Stud 49(6):785-800

Card D (2001) Immigrants inflows, native outflows, and the local labor market impacts of higher immigration. J Lab Econ 19(1):22-64

Chantavanich S, Jayagupta R (2009) Immigration to Thailand: the case of migrant workers from Myanmar, Laos, and Cambodia. In: Sagal U, Elliot D, Mayadas N (eds) Immigration worldwide: policies, practices, and trends. Oxford University Press, New York

De New JP, Zimmermann KF (1994) Native wage impacts of foreign labour: a random effects panel analysis. J Popul Econ 7:177-192

Dolado J, Goria A, Ichino A (1994) Immigration, human capital and growth in the host country. J Popul Econ 7(2):193-215 Garofalo GA, Yamarik S (2002) Regional convergence: evidence from a new state-by-state capital stock series. Rev Econ Statist 84(2):316-323

Greene WH (2003) Econometric analysis. Prentice Hall, New Jersey

Hujo K, Piper N (eds) (2010) South-south migration: Implications for social policy and development. Palgrave Macmillan, London

Hunt J (2011) Which immigrants are most innovative and entrepreneurial? Distinctions by entry visa. J Lab Econ 29(3):417-457

Jitsuchon S (2012) Thailand in the middle-income trap. TDRI Q Rev 27(2):13-20

Jones C, Pimdee P (2017) Innovative ideas: Thailand 4.0 and the fourth industrial revolution. Asian Int J Soc Sci 17(1):4-35

Kanapathy V (2011) A computable general equilibrium analysis of migrant labour in Malaysia. In: Ahsan A, Abella M, Beath A, Huang Y, Luthria M, Van Nguyen T (eds) International migration and development in East Asia and the Pacific. World Bank, Washington DC

Kremer M (1993) Population growth and technological change: one million BC to 1990. Q J Econ 108(3):681-716 Lathapipat D (2010) The absorption of immigrants and its effects on the Thai wage structure. http://ssrn.com/abstr act $=1678278$

Lucas RE (1988) On the mechanics of economic development. J Monet Econ 22(1):3-42

Manning C, Bhatnagar P (2004) The movement of natural persons in Southeast Asia: how natural? http://hdl.handl e.net/1885/39963

Martin P (2007) The economic contribution of migrant workers to Thailand: towards policy development. International Labor Office, Bangkok

Office of the National Economic and Social Development Board of Thailand (2019) Table of Gross Regional and Provincial Product 2016. https://www.nesdb.go.th/nesdb_en/main.php?filename=national_account

Ortega F (2008) The short-run effects of a large immigration wave: Spain 1998-2008. https://www.semanticscholar.org/ paper/The-short-run-eects-of-a-large-immigration-wave\%3A-Ortega/673e1fc8628d36915d45d2ee0e75ead7f5d 5e9aa. Accessed 08 Jan 2019

Ottaviano Gl, Peri G (2008) Immigration and national wages: Clarifying the theory and the empirics. http://www.nber.org/ papers/w14188. NBER Working Paper No. 14188 posted July 2008

Ottaviano Gl, Peri G (2012) Rethinking the effect of immigration on wages. J Eur Econ Assoc 10(1):152-197

Paitoonpong S (2011) Different stream, different needs, and impact: Managing international labor migration in ASEAN: Thailand (immigration). No DP 2011-2028. https://econpapers.repec.org/RePEc:phd:dpaper:dp_2011-28/

Paitoonpong S, Chalamwong Y (2012) Managing International Labor Migration in ASEAN: A Case of Thailand. Thailand Development Research Institute (TDRI). http://hdl.handle.net/11540/6420

Peri G (2012) The effect of immigration on productivity: evidence from US states. Rev Econ Statist 94(1):348-358 
Pholphirul P (2013) Immigration, job vacancies, and employment dynamics: evidence from Thai manufacturers. J Asian Econ 24:1-16

Pholphirul P, Kamlai J (2014) How much do low-skilled immigrants contribute to the Thai economy?: analysis of three methodologies. Asian Pacific Migr J 23(1):85-112

Pholphirul P, Rukumnuaykit P (2010) Economic contribution of migrant workers to Thailand. Int Migr 48(5):174-202

Ratha D, Shaw W (2007) South-South migration and remittances. World Bank, Washington DC

Romer PM (1994) The origins of endogenous growth. J Econ Perspect 8(1):3-22

Solow RM (1956) A contribution to the theory of economic growth. Q J Econ 70(1):65-94

Sussangkarn C (1996) Macroeconomic impacts of migrant workers: analyses with a CGE model. TDRI Q Rev 11(3):3-11

Thangavelu SM (2012) Economic growth and foreign workers in ASEAN and Singapore. Asian Econ Pap 11(3):114-136

\section{Publisher's Note}

Springer Nature remains neutral with regard to jurisdictional claims in published maps and institutional affiliations.

Submit your manuscript to a SpringerOpen ${ }^{\circ}$ journal and benefit from:

- Convenient online submission

Rigorous peer review

- Open access: articles freely available online

- High visibility within the field

- Retaining the copyright to your article

Submit your next manuscript at $\boldsymbol{\nabla}$ springeropen.com 